\title{
AKTIVITAS ANTIBAKTERI EKSTRAK ETANOL DAUN JAMBU AIR [Eugenia aqueum (Burm. F) Alston] DENGAN MIKRODILUSI AGAR
}

\author{
Lanny Mulqie', Suwendar ${ }^{2}$, Muhammad Fakhrur Raji ${ }^{3}$, Dieni Mardliyani ${ }^{4}$, Imas \\ Yumniati ${ }^{5}$, Widiasari ${ }^{6}$, Adella Nursya'bani ${ }^{7}$, Zakiyyah Nurrosyidah $^{8}$
}

$1,2,3,4,5,6,7,8$ Program Studi Farmasi, Fakultas MIPA, Universitas Islam Bandung

Info Article

Submitted :

21 April 2021

Revised:

17 Juli 2021

Accepted :

27 September 2021

\section{Corresponding Author :}

Lanny Mulqie

Email :

lannymulqie.26@gmail.com

\section{ABSTRAK}

Sumber daya alam yang dimiliki Indonesia cukup berlimpah. Tanaman merupakan sumber daya alam yang banyak dimanfaatkan sebagai obat. Salah satu tanaman obat yang dapat digunakan sebagai obat tradisional adalah jambu air. Tujuan penelitian ini yaitu untuk melihat aktivitas antibakteri ekstrak etanol daun jambu air terhadap S. aureus, dan E.coli dan penetapan nilai Konsentrasi Hambat Minimum (KHM), serta pengujian Konsentrasi Bunuh Minimum (KBM). Ekstraksi dilakukan secara maserasi dengan etanol 96\%. Pengujian aktivitas antibakteri dan penetapan KHM dilakukan dengan metode mikrodilusi agar. Penetapan KBM dilakukan dengan menentukan bagian media agar yang menunjukkan tidak adanya pertumbuhan bakteri dengan hasil visual yang jernih. Nilai KHM dan KBM ekstrak etanol daun jambu air terhadap S. aureus, dan E.coli yaitu $20.000 \mu \mathrm{g} / \mathrm{mL}$ dan $40.000 \mu \mathrm{g} / \mathrm{mL}$.

Kata kunci: ekstrak etanol, jambu air, mikrodilusi agar
Access this article

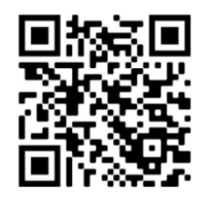

SCAN ME
ABSTRACT

Indonesia's natural resources are quite abundant. Plants are natural resources that are widely used as medicine. One of the medicinal plants that can be used as traditional medicine is the watery rose apple. This study aimed to determine the antibacterial activity of the ethanol extract of watery rose apple leaves against $\mathrm{S}$. aureus and $E$. coli, determine the value of the Minimum Inhibitory Concentration (MIC), and Minimum Bactericidal Concentration (MBC). Extraction was carried out by maceration with $96 \%$ ethanol. MIC was determined using the agar microdilution method. Determination of $\mathrm{MBC}$ is done by determining the part of the agar medium which shows the absence of bacterial growth with clear visual results. The MIC and MBC values of watery rose apple leaves ethanol extract against $\mathrm{S}$. aureus and E. coli were $20,000 \mathrm{~g} / \mathrm{mL}$ and $40,000 \mathrm{~g} / \mathrm{mL}$, respectively. 


\section{Keywords: ethanol extract, watery rose apple, broth} microdilution

\section{PENDAHULUAN}

Sumber daya alam yang dimiliki Indonesia cukup berlimpah. Tanaman merupakan sumber daya alam yang banyak dimanfaatkan sebagai obat. Jambu air merupakan tanaman yang banyak digunakan sebagai obat tradisional. Daun jambu air memiliki aktivitas sebagai antibiotika (Sonawane, 2018). Ekstrak metanol daun jambu air memiliki aktivitas antioksidan, antiinflamasi, analgesik, dan hepatoprotektor (Sobeh et al, 2018). Ekstrak etanol daun jambu air memiliki aktivitas antidiabetes dan berpengaruh terhadap penurunan kadar kreatinin dan ureum pada tikus yang diinduksi streptozotosin (Tandi, 2017). Ekstrak metanol dan etil asetat dari daun dan kulit batang jambu air memiliki aktivitas antioksidan yang sangat kuat terhadap radikal bebas 1,1-difenil-2-pikrilhidrazil (DPPH) dan hidrogen peroksida. Sedangkan ekstrak metanol, etil asetat dan heksana dari daun dan kulit batang jambu air memiliki aktivitas sitotoksik terhadap larva udang (Itam et al, 2021). Berdasarkan hasil uji toksisitas akut dan subkronis yang dilakukan terhadap hewan uji dikatakan bahwa ekstrak daun jambu air tidak menunjukkan adanya tanda-tanda toksisitas, sehingga dapat dikatakan bahwa ekstrak daun jambu air bebas dari risiko toksik. (Manaharan, 2014).

Selain itu, daun jambu air juga berpotensi sebagai antibakteri. Penelitian yang sudah dilakukan mengenai aktivitas antibakteri daun jambu air menunjukkan bahwa ekstrak etanol daun jambu air memiliki aktivitas antibakteri terhadap bakteri isolat klinis dengan menggunakan metode difusi agar, namun dalam penelitian ini KHM ekstrak tidak dapat ditentukan (Hariyati dkk, 2015). Fraksi etil asetat daun jambu air bekerja sebagai bakterisid terhadap terhadap S. aureus, dan E.coli (Choesrina dkk, 2019). KHM fraksi n-heksana terhadap S. aureus, dan E.coli adalah 3,13\% dan 1,56\% (Suwendar dkk, 2020). Fraksi air daun jambu air berpotensi sebagai bakterisid terhadap $\mathrm{S}$. aureus, dan E.coli dengan KHM masingmasing sebesar $0,78 \%$. Tujuan penelitian ini yaitu untuk melihat aktivitas antibakteri ekstrak etanol daun jambu air dan penetapan nilai Konsentrasi Hambat Minimum (KHM) dengan metode mikrodilusi agar, serta pengujian Konsentrasi Bunuh Minimum (KBM). Melalui penelitian ini diharapkan melengkapi informasi tentang aktivitas antibakteri daun jambu air sehingga potensi daun jambu air didasari oleh bukti ilmiah yang cukup lengkap.

\section{METODE PENELITIAN}

\subsection{Alat}

Biosafety cabinet, timbangan analitik (Sartorius), maserator, rotary vacuum evaporator (Buchi), gelas kimia, batang pengaduk, mortar, stamper, pelat mikro, inkubator (Memmert), spektrofotometer UV-visible, vortex, cawan petri, jarum ose, lampu spiritus, autoklaf, pipet Eppendorf, pipet ukur.

\subsection{Bahan}

Daun jambu air, etanol 96\%, amoksisilin, siprofloksasin, Mueller Hinton 
Agar (MHA), Mueller Hinton Broth (MHB), dimetilsulfoksida (DMSO), kapas berlemak, aluminium foil, aquades.

\subsection{Bakteri Uji}

Bakteri uji yang digunakan yaitu Staphylococcus aureus (S. aureus) dan Escherichia coli (E. coli) yang diperoleh dari Laboratorium Farmasi Terpadu Unit D, Prodi Farmasi FMIPA UNISBA.

\subsection{Pengolahan Bahan dan Penyiapan Simplisia}

Pengolahan bahan dimulai dengan sortasi basah yang dilakukan untuk memisahkan kotoran-kotoran atau bahanbahan asing lainnya dari bahan. Setelah itu dilakukan pencucian pada bahan untuk menghilangkan tanah dan pengotor lain yang melekat pada bahan. Setelah bahan uji bersih, dilakukan pengeringan untuk mendapatkan simplisia yang tidak mudah rusak, sehingga dapat disimpan lama. Pengeringan dilakukan dengan cara diangin-angin dan tidak di bawah sinar matahari langsung yang bertujuan untuk menghindari hilangnya senyawa aktif yang mudah menguap. Setelah proses pengeringan, dilakukan sortasi kering untuk memisahkan benda-benda asing seperti bagian-bagian tanaman yang tidak diinginkan dan pengotor-pengotor lain yang masih tertinggal pada simplisia kering. Simplisia kering selanjutnya digiling dengan menggunakan blender sehingga diperoleh simplisia dalam bentuk serbuk (Depkes RI, 1985).

\subsection{Determinasi Tanaman Uji}

Deterninasi tanaman daun jambu air dilakukan di Sekolah IImu Teknologi Hayati, Institut Teknologi Bandung.

\subsection{Ekstraksi}

Ekstraksi dilakukan secara maserasi dengan menggunakan etanol 96\% sebagai pelarut. Sebanyak 50 gram simplisia daun jambu air direndam dalam $1 \mathrm{~L}$ etanol $96 \%$ selama $5 \times 24$ jam pada suhu kamar, kemudian disaring menggunakan kertas saring sehingga diperoleh ekstrak cair. Ekstrak cair yang diperoleh diuapkan dengan rotary vacuum evaporator dan disimpan pada water bath suhu $50^{\circ} \mathrm{C}$ hingga diperoleh ekstrak kental (Suwendar dkk, 2014).

\subsection{Sterilisasi Media dan Alat}

Sterilisasi dilakukan terhadap media dan alat dengan menggunakan autoklaf pada suhu $121^{\circ} \mathrm{C}$ selama 15 menit.

\subsection{Penyiapan MHA dan MHB}

Mueller Hinton Agar (MHA) dibuat dengan melarutkan 38 gram serbuk MHA dalam air suling steril sebanyak $1000 \mathrm{~mL}$. Sedangkan Mueller Hinton Broth (MHB) dibuat dengan melarutkan 21 gram serbuk MHB dalam air suling steril sebanyak 1000 $\mathrm{mL}$. Kemudian masing-masing dipanaskan hingga larut dalam labu Erlenmeyer, disumbat dengan kapas berlemak dan ditutup dengan alumunium foil lalu disterilkan dengan autoklaf pada suhu $121^{\circ} \mathrm{C}$ selama 15 menit.

\subsection{Penyiapan Sediaan Uji dan Antibiotika Pembanding}

Sediaan uji yang digunakan yaitu ekstrak etanol daun jambu air dengan konsentrasi uji $80.000 \mu \mathrm{g} / \mathrm{ml}$ yang dimasukan ke dalam kolom 12. Antibiotika yang digunakan yaitu amoksisilin dan siprofloksasin dengan konsentrasi 1000 $\mu \mathrm{g} / \mathrm{ml}$.

\subsection{Penyiapan Suspensi Bakteri Uji}

Suspensi bakteri uji dilakukan dengan cara membiakkan bakteri uji yaitu S. aureus dan E. coli pada media pertumbuhan Mueller Hinton Broth (MHB) dan diinkubasi pada suhu $37^{\circ} \mathrm{C}$ selama 18 - 
24 jam. Pada suspensi bakteri yang sudah diinkubasi dilakukan pengenceran dengan MHB sampai diperoleh kekeruhan suspensi bakteri dengan mengukur nilai absorbansinya (A) menggunakan spektrofotometer UV-Vis pada panjang gelombang $(\lambda) 625 \mathrm{~nm}$ sampai diperoleh nilai $A=0,08-0,13$. Kekeruhan ini menunjukkan sekitar $1 \times 10^{8} \mathrm{CFU} / \mathrm{mL}$ bakteri. Pada suspensi tersebut dilakukan pengenceran dengan perbandingan 1:20 sehingga terdapat bakteri $5 \times 10^{6} \mathrm{CFU} / \mathrm{mL}$. Supensi bakteri inilah yang nanti akan dimasukkan ke dalam sumur pada pelat mikro (CLSI, 2012 dan Sukandar dkk, 2014).

\subsection{Pengujian Aktivitas Antibakteri Ekstrak Etanol Daun Jambu Air dengan Mikrodilusi Agar dan Penetapan KHM}

Sebanyak $100 \mu \mathrm{L}$ MHB dimasukan ke dalam semua kolom. Ekstrak uji dimasukan ke dalam kolom 12, baris A, B, C. Larutan siprofloksasin dimasukan ke dalam kolom 12 baris D, E, F. Larutan amoksisilin dimasukan ke dalam kolom 12 baris $G$ dan $\mathrm{H}$. Volume masing-masing sediaan yang dimasukkan ke kolom 12 yaitu $100 \mu \mathrm{L}$, sehingga pada kolom 12 terdapat $100 \mu \mathrm{L}$ MHB dan $100 \mu \mathrm{L}$ sediaan. Dari campuran tersebut diambil sebanyak $100 \mu \mathrm{L}$ untuk mengisi kolom 11. Pengenceran tersebut dilakukan berurutan hingga ke kolom 3 . Pada setiap sumur kecuali sumur kolom 1 diisi $10 \mu \mathrm{L}$ suspensi bakteri yang sudah mengalami pengenceran sehingga pada masing-masing sumur terdapat $5 \times 10^{4}$ $\mathrm{CFU} / \mathrm{mL}$. Kolom 1 pelat mikro digunakan sebagai kontrol negatif, kolom 2 sebagai kontrol positif. Dilakukan inkubasi pada suhu $37^{\circ} \mathrm{C}$ selama $18-24$ jam kemudian diamati ada atau tidaknya pertumbuhan bakteri pada tiap sumur dengan melihat kejernihan kultur dibandingkan dengan kontrol. Apabila keruh maka bahan uji tidak dapat menghambat pertumbuhan bakteri. Bila kultur jernih maka bahan uji dapat menghambat pertumbuhan bakteri. Konsentrasi terendah yang tidak ditumbuhi bakteri (jernih) ditetapkan sebagai nilai KHM.

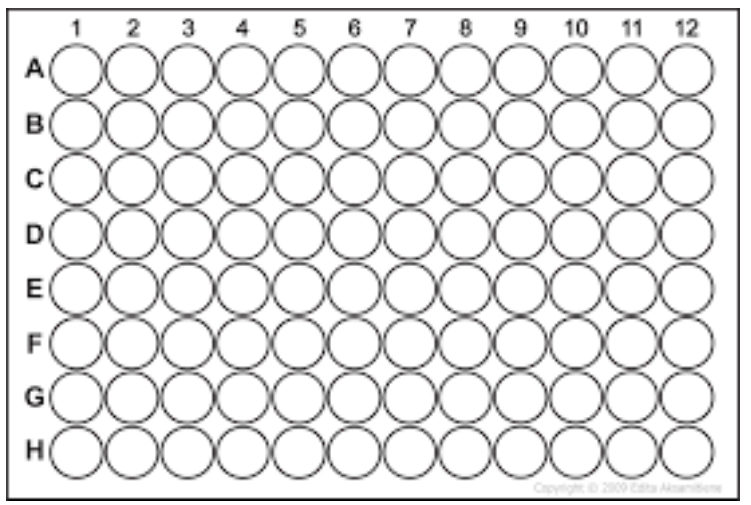

Gambar 1. Sumur Pada Pelat Mikro

\subsection{Pengujian KBM}

Sebanyak $15 \mathrm{~mL}$ MHA dicairkan dan dibiarkan hingga mencapai suhu $45-53^{\circ} \mathrm{C}$, kemudian dituangkan ke dalam cawan petri steril dan dibiarkan selama beberapa menit sehingga menjadi padat. Pada sumur pelat mikro yang menunjukkan kejernihan, dipipet sejumlah $5 \mu \mathrm{L}$ alikuot. Alikuot tersebut kemudian digoreskan menggunakan ose diatas media MHA steril. Selanjutnya dilakukan inkubasi selama $18-24$ jam pada suhu $37^{\circ} \mathrm{C}$. Bagian media agar yang menunjukkan tidak adanya pertumbuhan bakteri dengan hasil visual yang jernih ditetapkan sebagai nilai KBM.

\section{HASIL DAN PEMBAHASAN}

Ekstraksi simplisia daun jambu air sebanyak 482,12 g dilakukan dengan cara maserasi menggunakan etanol 96\% sebagai pelarut. Metode maserasi dipilih untuk mengantisipasi kerusakan senyawa yang tidak stabil terhadap pemanasan. Ekstrak yang diperoleh kemudian diuapkan dengan rotary vacuum 
evaporator hingga didapat $85,12 \mathrm{~g}$ ekstrak kental dengan rendemen sebesar $17,65 \%$. Hasil uji aktivitas antibakteri ekstrak daun jambu air terhadap S. aureus dan E.coli dengan mikrodilusi agar dapat dilihat pada Tabel 1. dan Tabel 2.

Tabel 1. Penetapan Konsentrasi Hambat Minimum Ekstrak Daun Jambu Air terhadap S. aureus dengan Mikrodilusi Agar

\begin{tabular}{ccccccccccccc}
\hline \multirow{2}{*}{ Sediaan Uji } & \multicolumn{10}{c}{ Kolom } \\
\cline { 2 - 12 } & $\mathrm{K}(-)$ & $\mathrm{K}(+)$ & $\mathbf{3}$ & $\mathbf{4}$ & $\mathbf{5}$ & $\mathbf{6}$ & $\mathbf{7}$ & $\mathbf{8}$ & $\mathbf{9}$ & $\mathbf{1 0}$ & $\mathbf{1 1}$ & 12 \\
\hline EDJA & - & + & + & + & + & + & + & + & + & + & - & - \\
EDJA & - & + & + & + & + & + & + & + & + & + & - & - \\
EDJA & - & + & + & + & + & + & + & + & + & + & - & - \\
Siprofloksasin & - & + & + & + & + & - & - & - & - & - & - & - \\
Siprofloksasin & - & + & + & + & + & - & - & - & - & - & - & - \\
Siprofloksasin & - & + & + & + & + & - & - & - & - & - & - & - \\
Amoksisilin & - & + & + & + & + & + & + & + & + & - & - & - \\
Amoksisilin & - & + & + & + & + & + & + & + & + & - & - & - \\
\hline
\end{tabular}

\section{Keterangan:}

EDJA = ekstrak daun jambu air

$\mathrm{K}(+) \quad=$ kontrol positif

$\mathrm{K}(-) \quad=$ kontrol negatif

Kolom $4=$ EDJA 156,25 $\mu \mathrm{g} / \mathrm{mL}$, siprofloksasin dan amoksisilin 3,90 $\mu \mathrm{g} / \mathrm{mL}$

Kolom $5=$ EDJA 312,5 $\mu \mathrm{g} / \mathrm{mL}$, siprofloksasin dan amoksisilin $7,81 \mu \mathrm{g} / \mathrm{mL}$

Kolom $6=$ EDJA $625 \mu \mathrm{g} / \mathrm{mL}$, siprofloksasin dan amoksisilin 15,63 $\mu \mathrm{g} / \mathrm{mL}$

Kolom $7=$ EDJA $1.250 \mu \mathrm{g} / \mathrm{mL}$, siprofloksasin dan amoksisilin $31,25 \mu \mathrm{g} / \mathrm{mL}$

Kolom $8=$ EDJA $2.500 \mu \mathrm{g} / \mathrm{mL}$, siprofloksasin dan amoksisilin $62,5 \mu \mathrm{g} / \mathrm{mL}$

Kolom $9=$ EDJA $5.000 \mu \mathrm{g} / \mathrm{mL}$, siprofloksasin dan amoksisilin $125 \mu \mathrm{g} / \mathrm{mL}$

Kolom $10=$ EDJA $10.000 \mu \mathrm{g} / \mathrm{mL}$, siprofloksasin dan amoksisilin $250 \mu \mathrm{g} / \mathrm{mL}$

Kolom $11=$ EDJA $20.000 \mu \mathrm{g} / \mathrm{mL}$, siprofloksasin dan amoksisilin $500 \mu \mathrm{g} / \mathrm{mL}$

Kolom $12=$ EDJA $40.000 \mu \mathrm{g} / \mathrm{mL}$, siprofloksasin dan amoksisilin $1000 \mu \mathrm{g} / \mathrm{mL}$

(+) = ada pertumbuhan bakteri (keruh)

$(-) \quad=$ tidak ada pertumbuhan bakteri (bening)

Pada Tabel 1. Dapat diamati bahwa ekstrak daun jambu air memiliki aktivitas antibakteri terhadap S. aureus yang diuji dengan metode mikrodilusi agar. Hal ini ditunjukkan dengan terjadinya hambatan pertumbuhan pada kolom 11 (konsentrasi $20.000 \mu \mathrm{g} / \mathrm{mL}$ ) dan 12 (konsentrasi 40.000 $\mu \mathrm{g} / \mathrm{mL}$ ). Nilai KHM ekstrak daun jambu air terhadap S. aureus yaitu $20.000 \mu \mathrm{g} / \mathrm{mL}$.

Tabel 2. Penetapan Konsentrasi Hambat Minimum Ekstrak Daun Jambu Air terhadap E. coli dengan Mikrodilusi Agar

\begin{tabular}{cccccccccccccc}
\hline \multirow{2}{*}{ Sediaan Uji } & \multicolumn{10}{c}{ Kolom } \\
\cline { 2 - 12 } & $\mathrm{K}(-)$ & $\mathrm{K}(+)$ & $\mathbf{3}$ & $\mathbf{4}$ & $\mathbf{5}$ & $\mathbf{6}$ & $\mathbf{7}$ & $\mathbf{8}$ & $\mathbf{9}$ & $\mathbf{1 0}$ & $\mathbf{1 1}$ & 12 \\
\hline EDJA & - & + & + & + & + & + & + & + & + & + & - & - \\
EDJA & - & + & + & + & + & + & + & + & + & + & - & - \\
EDJA & - & + & + & + & + & + & + & + & + & + & - & - \\
Siprofloksasin & - & + & - & - & - & - & - & - & - & - & - & - \\
Siprofloksasin & - & + & - & - & - & - & - & - & - & - & - & - \\
Siprofloksasin & - & + & - & - & - & - & - & - & - & - & - & -
\end{tabular}




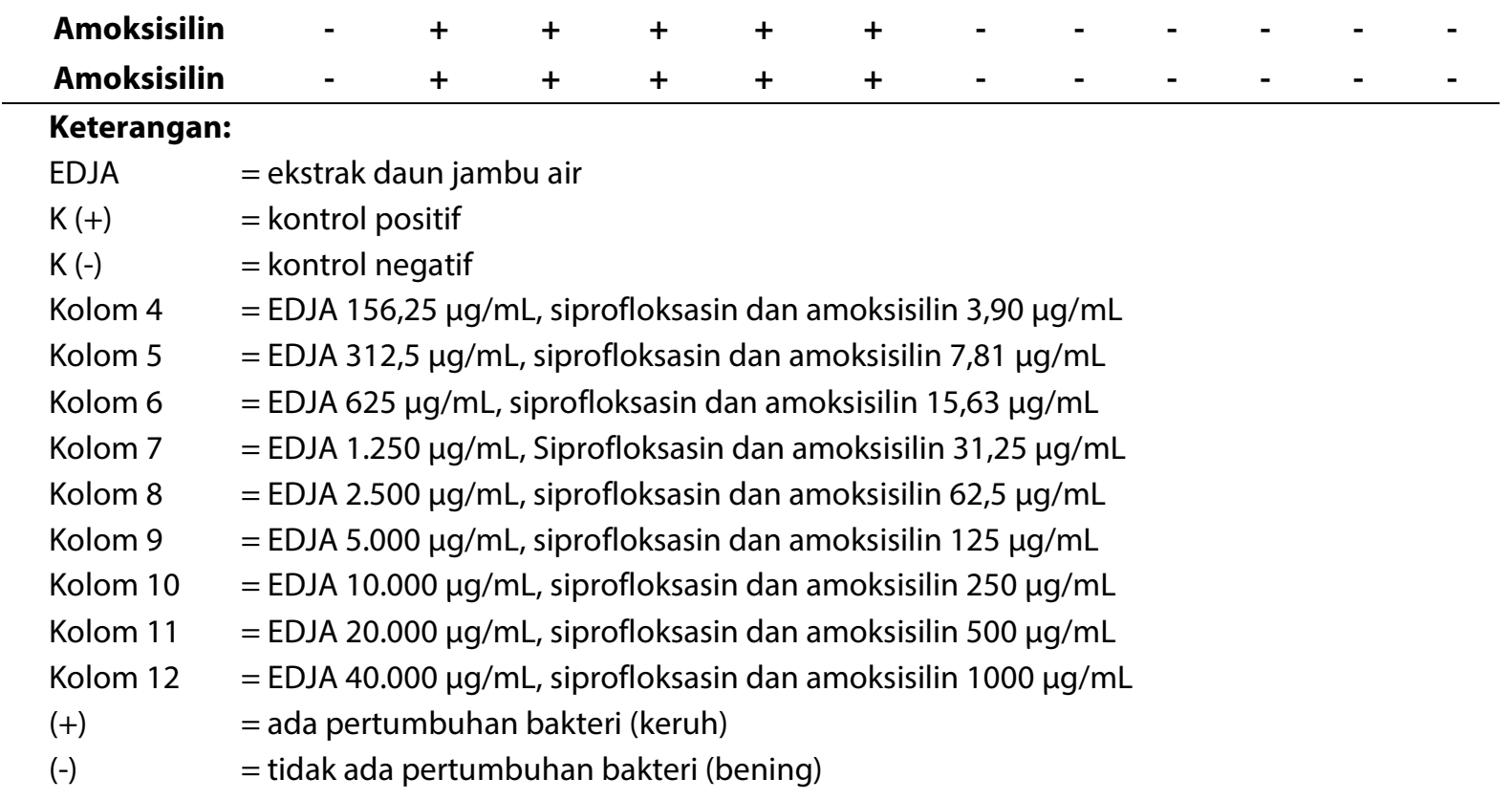

Pada Tabel 2. Dapat dilihat bahwa Hasil pengujian Konsentrasi Bunuh ekstrak daun jambu air memiliki aktivitas Minimum (KBM) terhadap S. aureus dan $E$. antibakteri terhadap E. coli dan nilai KHM coli dapat dilihat pada Gambar 2 dan Tabel ditetapkan pada konsentrasi $20.000 \mu \mathrm{g} / \mathrm{ml}$.

4.

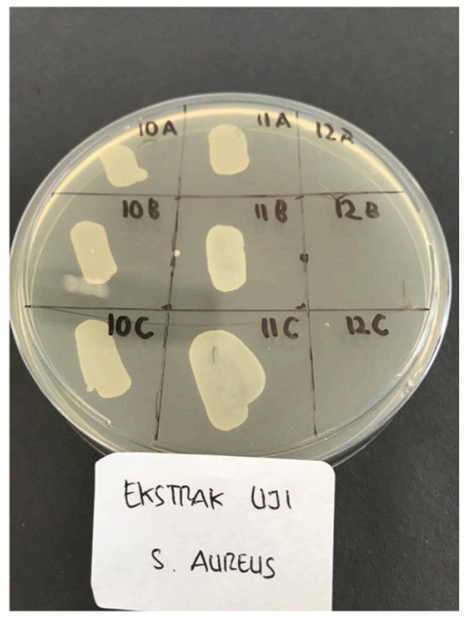

(A)

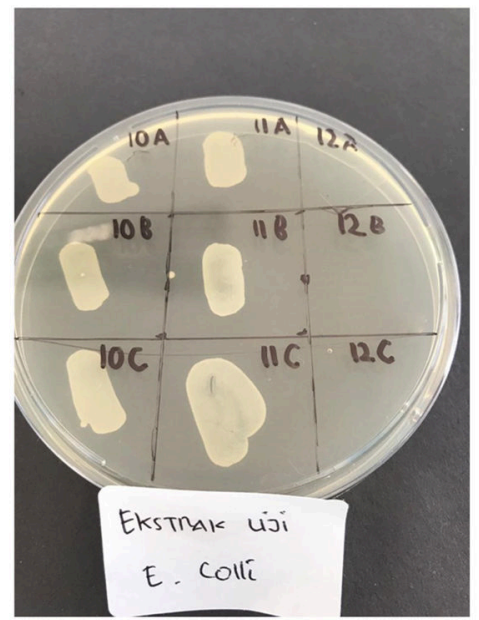

(B)

Gambar 2. Hasil pengujian KBM ekstrak etanol daun jambu air, (A) S. aureus, (B) E. coli, (10A, B, C) EDJA $10.000 \mu \mathrm{g} / \mathrm{mL}$, (11 A, B, C) EDJA $20.000 \mu \mathrm{g} / \mathrm{mL}$, (12A, B, C) EDJA $40.000 \mu \mathrm{g} / \mathrm{Ml}$

Pada Gambar 2. dapat diamati bahwa pada konsentrasi $10.000 \mu \mathrm{g} / \mathrm{mL}$ dan 20.000 $\mu \mathrm{g} / \mathrm{mL}$ ekstrak etanol daun jambu air masih terdapat pertumbuhan bakteri S. aureus maupun E. coli, sedangkan pada konsentrasi $40.000 \mu \mathrm{g} / \mathrm{mL}$ tidak menunjukkan adanya pertumbuhan bakteri $S$. aureus maupun $E$. coli dengan hasil visual yang terlihat jernih. 
Tabel 4. Hasil Pengujian KBM

\begin{tabular}{cccc}
\hline \multirow{2}{*}{ Konsentrasi EDJA $(\boldsymbol{\mu g} / \mathbf{m L})$} & \multicolumn{3}{c}{ Bakteri Uji } \\
\cline { 2 - 4 } & S. aureus & E. coli \\
\hline 10.000 & + & + \\
20.000 & + & + \\
40.000 & - & - \\
\hline
\end{tabular}

\section{Keterangan:}

EDJA = ekstrak daun jambu air

(+) = terdapat pertumbuhan bakteri

$(-) \quad=$ tidak terdapat pertumbuhan bakteri

Penetapan nilai KBM dilakukan dengan melihat konsentrasi terkecil yang menunjukkan tidak adanya pertumbuhan bakteri pada media agar. Pada Tabel 4. Dapat ditetapkan bahwa nilai KBM ektrak etanol terhadap S. aureus dan E. coli sebesar $40.000 \mu \mathrm{g} / \mathrm{mL}$.

Senyawa metabolit sekunder pada daun jambu air yang memiliki aktivitas antimikroba adalah flavonoid, tannin, alkaloid, dan steroid (Mapatac and Mamaoag, 2014). Pertumbuhan bakteri dapat dihambat oleh flavonoid melalui perusakan dinding sel, inaktivasi enzim, pengikatan adhesin. Gugus hidroksil pada cincin beta flavonoid berperan penting pada aktivitas antibakteri (Cowan, 1999; Nugraha dkk, 2017). Tannin dapat menghambat pertumbuhan bakteri dengan mengikat protein dan adhesin, menghambat kerja enzim, merusak dinding sel dan membran sel, sedangkan alkaloid bekerja dengan cara menghambat sintesis DNA (Cowan, 1999). Steroid memiliki aktivitas antibakteri karena dapat berikatan dengan lipid membran dan menyebabkan kebocoran liposom (Madduluri et al, 2013).

\section{KESIMPULAN}

Ekstrak daun jambu air memiliki aktivitas antibakteri terhadap S.aureus dan E. coli dengan metode mikrodilusi agar. Nilai KHM ekstrak daun jambu air terhadap S.aureus dan E. coli adalah $20.000 \mu \mathrm{g} / \mathrm{mL}$.
Nilai KBM ekstrak daun jambu air terhadap S.aureus dan E. coli adalah $40.000 \mu \mathrm{g} / \mathrm{mL}$.

\section{UCAPAN TERIMA KASIH}

Alhamdulillah puji dan syukur dipanjatkan kepada Alloh SWT karena atas pertolongan-Nya lah artikel ini dapat diselesaikan. Terima kasih disampaikan kepada Prodi Farmasi Fakultas Matematika dan IImu Pengetahuan Alam UNISBA dan Laboratorium Farmasi Terpadu Unit D Prodi Farmasi UNISBA yang telah memberikan bantuan sehingga penelitian ini dapat dilaksanakan.

\section{DAFTAR PUSTAKA}

Choesrina R., Suwendar, Mulqie L., Mardliyani D., 2019. Potensi Aktivitas Antibakteri dari Daun jambu Air [Eugenia aqueum (Burm. F) Alston] Terhadap Staphylococcus aureus dan Escherichia coli, Jurnal Ilmiah Farmasi Farmasyifa, 2(1): 33-39

CLSI, 2012. Method for Dilution Antimicrobial Susceptibillity Testing for Bacteria that Grow Aerobically; Clinical and Laboratory Standard Institute, approve Standard-Ninth Edition, M07-A9, Vol 32 No.2

Cowan MM., 1999. Plant Products as Antimicrobial Agents. Clinical Microbiolgy Reviews, 12 (4): 564-582

Departemen Kesehatan Republik Indonesia, 1985. Cara Pembuatan Simplisia, Direktorat Jenderal Pengawasan Obat dan Makanan, Jakarta, 4-15

Hariyati T., Jekti DSD., Andayani Y., 2015. Pengaruh Ekstrak Etanol Daun Jambu Air (Syzygium aqueum) Terhadap Bakteri Isolat Klinis, Journal Penelitian Pendidikan IPA, 1 (2): 31-38 
Itam A., Wati MS., Agustin V., Sabri N., Jumanah RA., Efdi M., 2021. Comparative Study of Phytochemical, Antioxidant, and Cytotoxic Activities and Phenolic Content of Syzygium aqueum (Burm. f. Alston f.) Extracts Growing in West Sumatera Indonesia, Hindawi The ScientificWorld Journal, 2021: 1-9

Sobeh M., Mahmoud MF., Petruk G., Rezq S., Ashour ML., Youssef FS., El-Shazly AM., Monti DM., Abdel-Naim AB., Wink M., 2018. Syzygium aqueum: A Polyphenol-Rich Leaf Extract Exhibits Antioxidant, Hepatoprotective, Pain-Killing and Antiinflammatory Activities in Animal Models, Frontiers in Pharmacology, 9 (566)

Sukandar EY., Fidrianny I., Triani R., 2014. Uji Aktivitas Antimikroba Ekstrak Etanol Buah Belimbing Wuluh (Averrhoa Bilimbi L.) terhadap Propionibacterium acnes, Staphylococcus epidermidis, MRSA dan MRCNS, Acta Pharmaceutica, 39(3\&4): 51-56

Suwendar S., Hazar S., Subarnas A., 2014. Uji Aktivitas Antioksidan Ekstrak Etanol Daun Jambu Air [Eugenia aqueum (Burm. F) Alston] secara in vitro dengan Metode Carotene Bleaching, Prosiding Seminar Nasional Penelitian dan Pengabdian pada Masyarakat : Sains, Teknologi dan Kesehatan, 4(1):31-36.

Suwendar S., Mulqie L., Choesrina R., Mardliyani D., 2020. Antibacterial Effect Potention of $n$ hexane Fraction of Rose Apple Leaves, Journal of Physics: Conf.Series, 1469012023

Madduluri S., Rao KB., Sitaram B., 2013. In Vitro Evaluation of Antibacterial Activity of Five Indigenous Plants Extract Against Five
Bacterial Pathogens of Human, International Journal of Pharmacy and Pharmaceutical Science, 5(4): 679-684

Manaharan T., Chakravarthi S., Radhakrishnan AK., Palanisamy UD., 2014. In vivi Toxicity Evaluation of A Standardized Extract of Syzygium aqueum Leaf, Elsevier, Toxicology Reports, 1 (718-725)

Mapatac LC., Mamaoag NR., 2014. Efficay of Three Varieties of Syzygium aqueum (Tambis) as Antimicrobial Agent and Its Bioactive Component, International Journal of Science adn Clinical Laboratory, 5(1):1

Mulqie L., Suwendar S., Choesrina R., Mardliyani D., Lestiyaningrum ED., Pratiwi ME., Fitri NN., 2020. Potensi Antibakteri Fraksi Air Daun Jambu Air [Eugenia aqueum (Burm. F) Alston] Terhadap Staphylococcus aureus dan Escherichia coli, Jurnal Ilmiah Farmasi Farmasyifa, 4(1): 98-104

Nugraha AC., Prasetya AT, Mursiti S., 2017. Isolasi, Identifikasi, Uji Aktivitas Senyawa Flavonoid sebagai Antibakteri dari Daun Mangga, Indonesian Journal of Chemical Science, 6(2)

Sonawane MS., 2018. Dietary Benefits of Watery Rose Apple (Syzygium aqueum (Burm.f.) Alston), International Archive of Applied Sciences and Technology, 9(4): 126-129

Tandi J., 2017. Pengaruh Ekstrak Etanol Daun Jambu Air (Syzygium aqueum (Burm f.)Alston) Terhadap Glukosa Darah, Ureum dan Kreatinin Tikus Putih (Rattus norvegicus), Journal of Tropical Pharmacy and Chemistry, 4(2): 43-51 